\title{
THE INFLUENCE OF GROWTH RETARDANTS AND CYTOKININS ON FLOWERING OF ORNAMENTAL PLANTS
}

\author{
Anna Pobudkiewicz \\ Research Institute of Pomology and Floriculture, Pomologiczna 18, 96-100 Skierniewice, Poland \\ e-mail: apobudk@insad.pl
}

Received: 14.09.2007

\section{S u m m a r y}

Growth retardants are applied in order to obtain short and well compact plants. They usually inhibit stem elongation, but also can influence the flowering of plants. The aim of cytokinin application is to obtain well branched plants without removing the apical meristem. Cytokinins usually increase the number of axillary shoots but also can influence flowering. Growth retardants and cytokinins can affect flower size, pedicel length, number of flowers, flower longevity, abortion of flower buds and number of days from potting plants to the first open flower. Flowering of growth retardant and cytokinin treated plants might depend on the method of growth regulator used (foliar spray or soil drench), plant species or even a plant cultivar, but in the highest degree it depends on the growth regulator rate used. These growth regulators, when are applied at rates appropriate for height and habit control, very seldom influence flowering of ornamental plants, but applied at high rates can delay flowering, diminish flower diameter or flower pedicel length and also can decrease the number of flowers per plant. In cultivation of bulb plants, growth retardants, used at very high rates, also cause abortion of flower buds.

Key words: growth retardants, cytokinins, ornamental plants, flowering

Growth retardants, applied in order to obtain short and well compact plants, inhibit stem elongation but also can influence flower size, pedicel length, number of flowers, flower longevity, abortion of flower buds and number of days from potting plants to their flowering. Cytokinins are used in order to obtain well branched plants without removing the apical meristem. They usually increase the number of axillary shoots but also can affect number of flowers, flower diameter, flower longevity and number of days to flowering.

\section{Number of flowers}

Growth retardants can have no influence on the number of flowers (Pobudkiewicz and Goldsberry, 1989 b; Pobudkiewicz and Nowak,
1992; Pobudkiewicz and Nowak, 1994 b; Whipker et al. 1994; P obudkiew ic z and Nowak, 1997) and also can reduce (P o budki e w i c z 2000 c; Pobudkiewicz et al. 2000) or increase (Yoo and Kang, 1999; Jung et al. 2000; W h i p k e r et al. 2000) the number of flowers. Cytokinins usually increase the number of flowers ( $\mathrm{J}$ a c k s o n , 1975; He in s et al. 1981; F a r in a, 1984; S o n g et al. 1991; Lee et al. 1999; Ferrante et al. 2006) or have no influence on flower number (V l a c h o s, 1985; T j i a, 1986; P o budki e w i c z, 2005). Flower number can depend on the method of growth retardant application. For example, S t a r m a n (1991) showed that uniconazole applied as a soil drench to Eustoma grandiflorum 'Yodel Blue' increased twice the number of flowers, but used as a foliar spray markedly decreased it. Other studies have shown that irrespectively of the method of growth retardant application, the number of flowers per plant was reduced. For example, Bougainvillea spectabilis drenched or sprayed with paclobutrazol had fewer flowers than control plants (K a r a g u z e 1, 1999). The number of flowers on the plant can also depend on the growth regulator rate and plant cultivar. For example, flurprimidol significantly decreased the number of flowering shoots in dwarf alstroemeria 'Rosalina' (at 7.5-22.5 mg $\times \mathrm{dm}^{-3}$ ) and at higher concentrations (15-

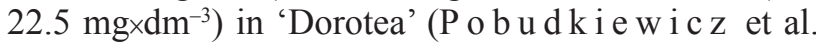
2000). Similarly, the number of Streptocarpus florets was decreased by flurprimidol at all tested concentra-

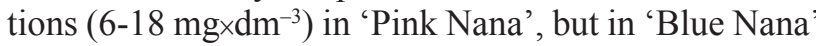
only at higher concentrations of $12-18 \mathrm{mg} \mathrm{dm}^{-3}(\mathrm{P} \mathrm{o}-$ b udkiew i c z, 2000 c). K i m et al. (2000) reported that Doritaenopsis 'Happy Valentine' sprayed with BA

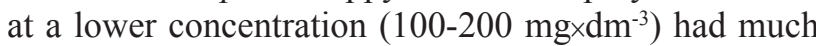
more flowers than plants treated with BA at higher concentrations of $400 \mathrm{mg} \times \mathrm{dm}^{-3}$. BAP at concentrations of $10-150{\mathrm{mg} \times \mathrm{dm}^{-3}}^{\mathrm{did}}$ not substantially affect flower production in Boronia heterophylla F. Muell. with 4 applications, but with 8 treatments there was a marked decli- 
ne in flowering with increased BAP concentration ( $\mathrm{R} \mathrm{i} \mathrm{-}$ c h a r d s, 1985). In Chamelaucium uncinatum Schauer 'Purple Pride' grown in pots, the timing of BA application was crucial for flowering ( $\mathrm{D}$ a w s o $\mathrm{n}$ and $\mathrm{K}$ in $\mathrm{g}$, 1993). Benzyladenine at $50 \mathrm{mg} \mathrm{dm}^{-3}$ either depressed or promoted flowering depending on the interval between BA treatment and exposure to short days. BA application 2 months before the start of short day treatment promoted flowering.

\section{Number of days to flowering}

In ornamental plants, growth retardants and cytokinins can delay flowering, accelerate it or have no influence on number of days from potting plants to their flowering. Delay of flowering is often observed, especially when growth regulators are applied at very high rates. For example, flurprimidol at high concentrations of 30-50 mgx $\mathrm{dm}^{-3}$, delayed flowering of asiatic hybrid lily 'Prima' by a few days (Pobudkiewicz and Nowak,

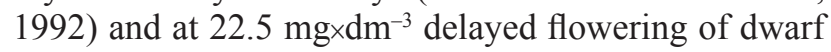
alstroemeria (P o budki e w i c z et al. 2000). F o le y and Keever (1991) reported that benzyladenine at

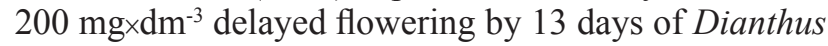
caryophyllus L. 'Knight Hybrid Scarlet'. The acceleration of flowering of growth retardant and cytokinin treated plants is not often observed. Following growth retardant application, earlier flowering was observed in Lisianthus (S t a rma n, 1991), Bougainvillea spectabilis Willd. (K a r a g u z e 1, 1999) or seed propagated geranium Pelargonium $\times$ hortorum L. H. Bailey $\left(\mathrm{P}_{\mathrm{o}-}\right.$ budkiew icz, 2000 c). Benzyladenine accelerated flowering in Zantedeschia elliottiana when the rhizome was soaked in BA solution (50-100 $\left.\mathrm{mg} \times \mathrm{dm}^{-3}\right) \mathrm{du}-$ ring 30 minutes, prior to potting ( $\mathrm{T} \mathrm{j} \mathrm{i} \mathrm{a} \mathrm{,} \mathrm{1986).} \mathrm{Earlier}$ flowering was also noticed in BA treated Bougainvillea 'Taipei Red' (Liang and Chang, 1998) and Oncidium 'Aloha' (L e e et al. 1999). Flowering time of growth retardant treated plants sometimes can depend on plant species. For example, days to flowering of pot carnation 'Snowmass' (P o budkiew ic z and Now a k, 1994 a) were unaffected by double flurprimidol treatment at very high concentration $\left(45 \mathrm{mg} \mathrm{dm}^{-3}\right)$, but this retardant at very low concentration $\left(7.5 \mathrm{mg} \times \mathrm{dm}^{-3}\right)$ delayed flowering of chrysanthemum cvs. 'Altis' and 'Surf' (P o b u d k i e w i c z and N o w a k, 1997). Other studies conducted on Eustoma grandiflorum 'Yodel Blue' (S t a rman, 1991) and Pelargonium $\times$ hortorum 'Red Elite' (Starman et al. 1994) showed that the method of growth retardant application influenced the number of days to anthesis. In those experiments, foliar uniconazole treatment delayed flowering by 3 days, but drench application accelerated flowering by 4 days. It was reported that flurprimidol spray treatment increased days to flowering in oriental lily 'Mona Lisa', while soil drench unaffected flowering ( $\mathrm{P}$ o b u d k i e wic z and Treder, 2006). The results of other stu- dies conducted on Dianthus (P o budk i ew i c z and N ow ak, 1994 a), Euphorbia (P o budki ew i c z et al. 1995), Pelargonium (P o bu d k i e w i c z and $\mathrm{No-}$ w a k, 1999), Globba (P o budki ew ic z and P odw y s z yńska, 1999), Cuphea (P obudki ew i c z, 2000 a), Streptocarpus (P obudkiewicz, 2000 b) and Lilium (P obudkiewicz and Treder, 2006) indicate that irrespective of growth retardant rate, plant species, or method of application, growth retardants had no influence on the number of days from potting plants to their flowering. Days to flowering of Cyclamem persicum 'Vuubaak' (S a k a i et al. 1979) and pot carnation 'Snowmass' (P o b u d k i e w i c z, 2005) were unaffected by BA at $50 \mathrm{mg} \times \mathrm{dm}^{-3}$ and $50-300{\mathrm{mg} \times \mathrm{dm}^{-3}}^{-3}$, respectively.

\section{Flower size}

The influence of growth regulators on flower size depends on plant species, method of application and growth regulator rate. Flower size of growth retardant treated plants can depend on plant species, or even a cultivar. For example, flurprimidol diminished the flower diameter of asiatic hybrid lily 'Prima' (P o b u d ki e w i c z and Nowak, 1992), but had no influence on the flower diameter of pot carnation 'Snowmass' (P o budkiewicz and Nowak, 1994 a). Both flurprimidol and daminozide had no influence on floret size of dwarf alstroemeria 'Dorotea', but those retardants diminished the floret size of 'Rosalina' (P o b u d k i e w i c $z$ et al. 2000). The method of growth retardant application affected the tepal length of oriental lily 'Mona Lisa' (P o bu d k i e w i c z and Tre d e r, 2006). Foliar flurprimidol treatments suppressed lily tepal length, but soil drench only had little effect on it. Growth retardants, when used at rates optimum to improve plant habit, might not influence the flower size (P o budkiewicz and Nowak, 1994 a; Pobudkiewicz and N ow a k, 1997), but when used at high rates they often slightly diminish flower diameter. For example, P obudki ew i c z and Treder (2006) reported that tepal length of 'Mona Lisa' was not suppressed by single flurprimidol spray at lower concentrations (10-20 $\left.m g \times \mathrm{dm}^{-3}\right)$, but higher concentrations $\left(30-40 \mathrm{mg} \mathrm{dm}^{-3}\right)$ and all double treatments $\left(10-40 \mathrm{mg} \mathrm{dm}^{-3}\right)$ significantly reduced tepal length, comparing with the control. A smaller flower diameter of plants treated with growth retardants at high rates was also observed in asiatic hybrid lily 'Prima' (Pobudkiewicz and Nowak, 1992), Poinsettia (P o b u d k i e w i c z et al. 1995), Pelargonium (P obudk i ew i c z and Now ak, 1999), Chrysanthemum indicum (J ung et al. 2000), Cuphea (P o b u d k i e w i c z, 2000 a) and Streptocarpus (P o budkiewicz, 2000 b). BA at $500 \mu \mathrm{M}$ diminished the inflorescence length of Salvia splendens Kerr Gawl 'Flamex 2000' (F e r r a n t e et al. 2006), but BA applied 
at concentrations of 50-300 mgx $\mathrm{dm}^{-3}$ had no influence on flower diameter of pot carnation 'Snowmass' (P o budki ew ic z, 2005).

\section{Flower pedicel length}

Growth regulators can influence the length of flower pedicel. Thanks to it, flowers are placed on the same level, what makes the plant very attractive. Floret pedicel length of seed propagated geranium Pelargonium $x$ hortorum L.H. Bailey depended on the geranium cultivar and the rate of flurprimidol ( $\mathrm{P} \mathrm{o} \mathrm{b} \mathrm{u} \mathrm{d} \mathrm{k} \mathrm{i} \mathrm{e} \mathrm{w} \mathrm{i} \mathrm{c} \mathrm{z,}$ $2000 \mathrm{c})$. The tested retardant at a low concentration $(7.5$ $m g \times \mathrm{dm}^{-3}$ ) had no effect on the pedicel length, but it markedly reduced it when used at the highest concentration $\left(22.5 \mathrm{mg} \mathrm{dm}^{-3}\right)$. Foliar spray of flurprimidol more efficiently diminished pedicel length of oriental lily 'Mona Lisa' than soil drench, which had only little effect on it (P obudki ew ic z and Treder, 2006). Shorter pedicels were also observed in dwarf pot roses 'Orange Sunblaze' (Pobudkiewicz and Goldsberry, 1989 a), asiatic hybrid lily 'Prima' (P o b u d k i e w i c z and Now ak, 1992) and chrysanthemum 'Altis' and 'Surf' (P o budki e w i c z and Now a k, 1997) following growth retardant application.

\section{Flower longevity}

Growth retardants and cytokinins used in order to improve plant habit sometimes influence flower longevity, but it does not happen very often. For example, floret longevity of dwarf alstroemeria 'Rosalina' and 'Dorotea' was significantly shorter, when flurprimidol was applied at concentrations of $15 \mathrm{mg} \times \mathrm{dm}^{-3}$ and above, but it was not affected by low concentration, $7.5 \mathrm{mg} \times \mathrm{dm}^{3}$ (P o b u d k i e w i c z et al. 2000). Greater flower longevity was observed in paclobutrazol treated Episcia $\mathrm{cu}$ preata 'Pink Panther' (S t a m p s and H e n n y, 1986). $\mathrm{BA}$ at $500 \mu \mathrm{M}$ prolonged the flower longevity of Salvia splendens Kerr Gawl cv. 'Flamex 2000' (F e rrante et al. 2006). Growth retardants had no influence on flower longevity of asiatic hybrid lily 'Prima' (P o b u d k i e w i z and Nowak, 1992), chrysanthemum cvs. 'Altis' and 'Surf' (P obudki ew icz and Nowak, 1997), Pelargonium (Pobudkiewicz and Nowak, 1999), Cuphea (P obudki ew icz, 2000 a), seed propagated geranium ( $\mathrm{P}$ o b u d k i e w i c z, 2000 c), easter lily cv. 'Nellie White' (R a n w a la et al. 2000) and oriental lily 'Mona Lisa' (P o budki ew i c z and Tred er, 2006).

\section{Flower bud abortion}

Flower but abortion is usually observed in bulb plants treated with growth retardants at very high rates. For example, there was no bud abortion observed when oriental lily 'Mona Lisa' was sprayed with flurprimidol once at (10-40 mg $\left.\times \mathrm{dm}^{-3}\right)$ and twice at lower concentra- tions (10-20 $\left.\mathrm{mg} \times \mathrm{dm}^{-3}\right)$. Double flurprimidol spray at higher concentrations increased the number of aborted buds. There were $19.4 \%$ and $32 \%$ of aborted buds on the plants treated with 30 and $40 \mathrm{mg} \mathrm{dm}^{-3}$, respectively (Pobudkiewicz and Treder, 2006). Similarly, in asiatic hybrid lily 'Prima' there was no bud abortion observed on the plants treated with flurprimidol at low concentration $\left(10 \mathrm{mg} \times \mathrm{dm}^{-3}\right)$ and on the control plants but higher concentrations: 20, 30, 40 and $50 \mathrm{mg} \times \mathrm{dm}^{-3}$ increased bud abortion by $8 \%, 25 \%, 50 \%$ and $58 \%$, respectively (P o bu d ki e w i c z and Now a k, 1992).

\section{REFERENCES}

Dawson I. A., King R. W., 1993. Effect of environment and applied chemicals on the flowering and form of Geraldton Wax (Chamelaucium uncinatum Schauer). Scientia Hortic. 54 (3): 233-246.

Farina E., 1984. The effects of 6-benzyladenine treatment on the yield of two Mediterranean carnation cultivars. Preliminary studies. Rivista Della Ortoflorofrut. Italiana, 68 (4): 307-315.

Ferrante A., Mensuali-Sodi A., Serra., Tognoni F., 2006. Evaluation of postproduction performance of Salvia splendens potted plants for interior use. Acta Hortic. (723): 415-419.

Foley J. T., Keever G. J., 1991. Growth regulators and pruning alter growth and axillary shoot development of Dianthus. J. Environ. Hort. 9 (4): 191-195.

Heins R. D., Armitage A. M., Carlson W. H., 1981. Influence of temperature, water stress and BA on vegetative and reproductive growth of Schlumbergera truncata. HortScience, 16 (5): 679-680.

Jacks on E. K., 1975. Increased yield of carnation cuttings and flowers by treatment with ACCEL Plant growth regulator. HortScience, 10 (3): 309.

Jung S. S., Jeong H. H., Kim K. S., 2000. Effects of uniconazole treatment on the growth and flowering of potted Chrysanthemum indicum L. Korean J. Hort. Sci. Techn. 18 (1): 28-32.

Karaguzel O., 1999. Effects of paclobutrazol on growth and flowering of Bougainvillea spectabilis Willd. Turkish J. Agric. Forestry, 23 (2): 527-532.

Kim T. J., Lee C. H., Paek K. Y., 2000 . Effects of growth regulators under low temperature environment on growth and flowering of Doritaenopsis 'Happy Valentine' during summer. J. Korean Soc. Hort. Sci. 41 (1): 101-104.

Lee J. S., Park B. M., Park H. B., 1999. Effects of GA3, BA, zeatin and kinetin on flowering of Oncidium 'Aloha' Korean J. Hort. Sci. Techn. 17 (2): 134-135.

Liang R. J., Chang Y. S., 1998. Effects of shading and growth regulators on the growth and flowering in bougainvillea. J. Chinese Soc. Hort. Sci. 44 (4): 429-437.

Pobudkiewicz A., 2000 a. The response of Cuphea ignea A.DC. to flurprimidol application. Folia Hortic. 12 (1): 99-106. 
Pobudkiewicz A., 2000 b. Controlling the growth habit of Streptocarpus hybridus with flurprimidol. J. Fruit Ornam. Plant Res. 8 (1): 9-17.

Pobudkiewicz A., 2000 c. Response of seed-propagated geranium (Pelargonium $\times$ hortorum L. H. Bailey) to application of flurprimidol. Acta Agrobot. 53 (1): 31-38.

Pobudkiewicz A., 2005. Wpływ 6-benzyloadeniny na krzewienie goździka doniczkowego. / The influence of benzyladenine on tillering of pot carnation. Zeszyty Probl. Post. Nauk Roln. (509): 209-214.

Pobudkiewicz A., Goldsberry K. L., 1989 a. Controlling the growth habit of dwarf pot roses with uniconazole (Sumagic). Col. Green. Grow. Res. Bul. 471: 1-2.

Pobudkiewicz A., Goldsberry K. L. 1989 b. Dwarf carnation response to soil application of Sumagic. Col. Green. Grow. Res. Bul. 474: 1-2.

Pobudkiewicz A., Nowak J., 1992. Effect of flurprimidol and silver thiosulphate (STS) on the growth and flowering of 'Prima' lilies grown as pot plants. Acta Hortic. 325: 193198.

Pobudkiewicz A., Nowak J., 1994 a. The influence of flurprimidol on the growth of the CMM dwarf Dianthus caryophyllus L. Cv. Snowmass. J. Fruit and Ornam. Plant Res. Vol II (4): 136-142.

Pobudkiewicz A., Nowak J., 1994 b. Wpływ retardantów wzrostu na wzrost i kwitnienie polskich odmian tulipanów uprawianych w doniczkach. / The influence of growth retardants on the growth and flowering of Polish potted tulip cultivars. Mat. Konf. Nauk. ,Tulips yesterday, today and tomorrow". Skierniewice, 13.05.1994: 31-38.

Pobudkiewicz A., Nowak J., 1997. Response of chrysanthemum (Dendranthema grandiflora Tzvelev) cvs. Altis and Surf to flurprimidol application. J. Fruit Ornam. Plant Res. 5 (1): 43-52.

Pobudkiewicz A., Nowak J., 1999. Wpływ regulatorów wzrostu na wzrost i kwitnienie Pelargonium $\times$ hortorum L. H. Bailey. / The influence of growth regulators on the growth and flowering of Pelargonium $\times$ hortorum L. H. Bailey. Acta Agrobot. (1-2): 127-137.

Pobudkiewicz A., Nowak J.S., Nowak J., 1995. Stosowanie nowego retardantu wzrostu - flurprimidol (Topflor $\left.{ }^{\circ}\right)$ w uprawie Euphorbia pulcherrima Willd. 'Lilo'/ Application of a new growth retardant - flurprimidol (Topflor ${ }^{\circ}$ ) in the cultivation of Euphorbia pulcherrima Willd. 'Lilo'. Mat. Konf. Nauk. „Nauka praktyce ogrodniczej”. Lublin, 1995: 879-882.

Pobudkiewicz A., Podwyszyńska M., 1999. The response of Globba winitii (Siam) to application of flurprimidol. Folia Hort. 11(1): 37-44.

Pobudkiewicz A., Nowak J., Podwyszyńska M., Przybyła A., 2000. The effect of growth retardants on growth and flowering of dwarf alstroemeria. Acta Agrobot. 53 (2): 77-84.

Pobudkiewicz A., Treder J., 2006. Effect of flurprimidol and daminozide on growth and flowering of oriental lily 'Mona Lisa'. Scientia Hortic. 110 (4): 328-333.

Ranwala A. P., Miller W. B., Kirk T. I., Hammer P. A., 2000. Ancymidol drenches, reversed greenhouse tempe- ratures, postgreenhouse cold storage, and hormone sprays effect postharvest leaf chlorosis in Easter lily. J. American Soc. Hortic. Sci. 125 (2): 248-253.

Richards D., 1985. Effect of cytokinin application and environment on growth and flowering of Boronia heterophylla $\mathrm{F}$. Meull. Scientia Hortic. 27 (3/4): 325-334.

Sakai K., Katano Y., Higuchi H., 1979. Promoting flowering in Cyclamen persicum by benzyladenine. Res. Bul. Aichi-Ken Agric. Res. Center 11: 81-87.

Song C.Y., Shin D. G., Woo I.S., Roh T. H., Ryu B. Y., Lee J. S., 1991. The effects of growth regulators and sowing date on growth and flowering in cyclamen. Res. Rep. Rural Develop. Administr. Hort. 33 (1): Korea Republic.

Starman T. W., 1991. Lisianthus growth and flowering responses to uniconazole. HortScience, 26 (2): 150-152.

Stamps R. H., Henny R. J. 1986. Paclobutrazol and night interruption lighting affect Episcia growth and flowering. HortScience, 21 (4): 1005-1006.

Starman T. W., Cerny T. A., Grindstaff T. L., 1994. Seed geranium growth and flowering responses to uniconazole. HortScience, 29 (8): 865-867.

Tjia B., 1986. Growth and flowering of container-grown calla lilies as affected by growth regulating chemicals. Proc. Inter. Soc. Trop. Hort. 30: 159-163.

Vlachos J. C., 1985. Effects of GA3 and BA on two cultivars of Achimenes longiflora under two levels of irradiance. Acta Hortic. 167: 225-235.

Whipker B. E., Dasoju S. K., Evans M. R., 2000. Vegetatively propagated geraniums respond similarly to drench applications of paclobutrazol or uniconazole. Hort Techn. 10 (1): 151-153.

Whipker B. E., Eddy R. T., Hammer P. A., 1994. Chemical growth retardant application to lisianthus. HortScience, 29 (11): 1368.

Yoo Y. K., Kang S. W., 1999. Effects of uniconazole treatment on the growth and flowering of Chrysanthemum zawadskii ssp. naktongense. J. Korean Soc. Hortic. Sci. 40 (4): 515-519.

\section{Wpływ retardantów wzrostu i cytokinin na kwitnienie roślin ozdobnych}

\section{Streszczenie}

Retardanty wzrostu, stosowane w celu uzyskania niskich i zwartych roślin, hamują wydłużanie się pędów, ale wpływają także na kwitnienie roślin. Cytokininy natomiast stosowane są głównie do stymulacji rozkrzewiania się roślin, bez usuwania wierzchołka pędu. Zwiększając liczbę pędów bocznych, poprawiają one pokrój rośliny, ale wpływają też na jej kwitnienie. Retardanty i cytokininy moga wpływać na wielkość kwiatu, długość szypułki kwiatowej, liczbę kwiatów na roślinie, trwałość kwiatu, liczbę dni od posadzenia do zakwitania roślin lub opadanie pąków kwiatowych. $\mathrm{Na}$ kwitnienie roślin traktowanych retardantem lub cy- 
tokininą mogą mieć wpływ: metoda stosowania regulatora wzrostu (dolistna lub do podłoża), gatunek rośliny a nawet i odmiana, ale w najwyższym stopniu wpływa stosowana dawka regulatora wzrostu. Retardanty lub cytokininy stosowane w dawkach odpowiednich do otrzymania roślin niskich i o dobrym pokroju, rzadko wpływają na ich kwitnienie, natomiast stosowane w wyso- kich dawkach mogą zwiększyć liczbę dni od posadzenia roślin do ich zakwitania, zmniejszyć wielkość kwiatu, skrócić szypułki kwiatowe oraz zmniejszyć liczbę kwiatów na roślinie. W uprawie roślin cebulowych, retardanty wzrostu stosowane w bardzo wysokich dawkach, powodują opadanie pąków kwiatowych. 
